\title{
Importance of Transplanted Onions Contributing to Late-Season Iris yellow spot virus Epidemics in New York
}

\author{
Ashley Leach, ${ }^{\dagger}$ Department of Entomology, Cornell University, New York State Agricultural Experiment Station, Geneva, NY 14456; Marc \\ Fuchs, Plant Pathology and Plant-Microbe Biology Section, School of Integrative Plant Science, Cornell University, New York State Agricul- \\ tural Experiment Station; Riley Harding, Department of Entomology, Cornell University, New York State Agricultural Experiment Station; \\ Rebecca Schmidt-Jeffris, Department of Plant and Environmental Sciences, Clemson University, Coastal Research and Education Center, \\ Charleston, SC 29414; and Brian A. Nault, Department of Entomology, Cornell University, New York State Agricultural Experiment Station
}

\begin{abstract}
Iris yellow spot virus (IYSV) is an economically significant tospovirus of onion transmitted by onion thrips (Thrips tabaci Lindeman). IYSV epidemics in onion fields are common in New York; however, the role of various habitats contributing to viruliferous onion thrips populations and IYSV epidemics is not known. In a 2-year field study in New York, the abundance of dispersing onion thrips, including those determined to be viruliferous via reversetranscriptase polymerase chain reaction, was recorded in habitats known to harbor both IYSV and its vector. Results showed that viruliferous thrips were

encountered in all habitats; however, transplanted onion sites accounted for 49 to $51 \%$ of the total estimated numbers of viruliferous thrips. During early to midseason, transplanted onion sites had 9 to 11 times more viruliferous thrips than the other habitats. These results indicate that transplanted onion fields are the most important habitat for generating IYSV epidemics in all onion fields (transplanted and direct-seeded) in New York. Our findings suggest that onion growers should control onion thrips in transplanted fields early in the season to minimize risk of IYSV epidemics later in the season.
\end{abstract}

Iris yellow spot virus (IYSV) (genus Tospovirus, family Bunyaviridae) is transmitted by onion thrips (Thrips tabaci Lindeman) and can cause extensive economic damage to onion. IYSV was originally described by Cortês et al. (1998) on Dutch iris (Iris hollandica Tub.) in the Netherlands. Since its first identification, IYSV has been isolated from 61 plant species in 27 countries (Bag et al. 2015; Gent et al. 2006). IYSV has a great economic impact on the commercial onion bulb and seed industry, in which yield losses can range between 60 and 100\% annually (Gent et al. 2006; Pozzer et al. 1999). Once infected with IYSV, diamond-shaped lesions appear on onion scapes and tan or straw-colored necrotic lesions form on leaves. In severe infections, these lesions coalesce, girdling the leaf or stem and causing dieback (De Avila et al. 1981). In an economic analysis conducted in 2003, onion growers in Colorado reported annual losses of approximately $\$ 2.5$ to 5 million due to IYSV infection (Gent et al. 2006).

Previous studies have indicated that IYSV is not seed transmitted, and mechanical inoculation is largely unsuccessful in onion (Bag et al. 2015; Kritzman et al. 2001). Thus, spread of IYSV is dependent on the acquisition and transmission of IYSV by onion thrips. Similar to other tospoviruses, IYSV is both circulative and propagative within its thrips vector, allowing adults to transmit the virus until death (Whitfield et al. 2005). Tospoviruses are acquired only by first and second instars (Whitfield et al. 2005): acquisition rates decrease as larvae mature (Ullman et al. 2002) because a midgut barrier develops, which prevents viral infection (Nagata et al. 1999). Unlike larvae, adults can disperse great distances and may infect multiple plants. Consequently, understanding the dispersal of thrips adults provides insight into the epidemiology of tospoviruses (Ullman et al. 2002).

Onion thrips is the only species known to transmit IYSV to onion and transmission efficiencies have been recorded as high as $76 \%$ or greater (Birithia et al. 2013; Srinivasan et al. 2012). A positive relationship between IYSV incidence in onion fields and onion thrips densities has been

${ }^{\dagger}$ Corresponding author: A. Leach; E-mail: al2282@cornell.edu

Funding: Funds from the New York Onion Research and Development program supported this study.

Accepted for publication 20 December 2017.

() 2018 The American Phytopathological Society documented by Kritzman et al. (2001) and Schwartz et al. (2009). Onion thrips have a strong preference for onion, despite their utilization of over 300 plant species as hosts (Doederlein and Sites 1993). Additionally, their populations can increase quickly, with seven or more generations produced in a year (Hoffman et al. 1996). These traits of host specificity and rapid population growth are critical factors influencing IYSV epidemics in onion fields (Gent et al. 2006). In addition to transmitting IYSV, onion thrips feeding also causes significant bulb yield reductions, ranging from 43 to $60 \%$ (Fournier et al. 1995; Rueda et al. 2007).

Currently, there are no IYSV-resistant onion cultivars (Cramer et al. 2014; Diaz-Montano et al. 2012). Therefore, virus management efforts are focused on reducing onion thrips populations during the growing season to reduce IYSV epidemics (Bag et al. 2015; Gent et al. 2006). Within the Unites States, additional efforts have been made to identify sources of IYSV inoculum in onion production systems to better understand its epidemiology and develop management strategies. Thus far, three different sources of inoculum within onion production systems have been identified: onion plants imported from the southwestern United States and then transplanted elsewhere, certain weed species, and volunteer onion bulbs in cull piles (Gent et al. 2006; Evans et al. 2009; Hsu et al. 2010, 2011; Nischwitz et al. 2012; Sampangi et al. 2007; Schwartz et al. 2014; Smith et al. 2011; Szostek and Schwartz 2015). The relative contribution of habitats containing these various sources of IYSV and its vector on IYSV epidemics in onion agroecosystems is not known.

Young onion plants imported from the southwestern United States and then transplanted and grown in commercial fields could be an important habitat affecting IYSV epidemics in all onion fields later in the season. In New York, some onion-growing areas are not established with transplants, whereas others may have as much as $35 \%$ of the area established with transplants. Gent et al. (2006) found that $50 \%$ of onion transplant lots tested positive for IYSV and were also infested with onion thrips. Hsu et al. (2011) assayed over 1,000 onion plants imported from the southwestern United States and found $0.5 \%$ infected with IYSV. Infection levels as low as $0.5 \%$ could create severe IYSV epidemics later in the season. Additionally, fields of transplanted onion are preferentially colonized over direct-seeded onion early in the season and can host large populations of onion thrips (Hsu et al. 2011). In New York, onion fields established with imported transplants from the southwestern United States and isolated from major onion-producing areas had severe epidemics of IYSV (over $75 \%$ of plants with symptoms) (B. Nault, personal observation). 
Habitats containing weeds near onion fields could be important contributors to IYSV epidemics in onion fields. At least 61 weed species have tested positive for IYSV, and approximately $30 \%$ are commonly encountered in onion production systems (Gent et al. 2006; Schwartz et al. 2014; Smith et al. 2011). Smith et al. (2011) identified four weed species (i.e., dandelion [Taraxacum officinale G. H. Weber ex Wiggers], common burdock [Arctium minus Bernh.], curly dock [Rumex crispus L.], and chicory [Cichorium intybus L.]) that were suitable hosts for both IYSV and onion thrips; therefore, these perennial or biennial weed species may provide a "green bridge" for IYSV between onion growing seasons in New York. Similar results with other plant species have been presented by Nischwitz et al. (2012) and Schwartz et al. (2014).

Habitats where onion bulb cull piles are located may be important to IYSV epidemiology in onion fields. Although cull piles are dominated by decomposing onion bulbs, bulbs that produce leaves also occur (i.e., volunteer onion plants). Volunteer onion plants, which grow from bulbs leftover from the previous year's onion crop, may enable IYSV to persist between growing seasons. Indeed, volunteer onion plants from cull piles have tested positive for IYSV in multiple studies (Gent et al. 2006; Hsu et al. 2011; Schwartz et al. 2014). In New York, $50 \%$ of onion cull piles examined had volunteer onion plants that tested positive for IYSV (Hsu et al. 2011). Furthermore, the probability of detecting viruliferous onion thrips in onion cull piles is largely dependent on the presence of volunteer onion plants, because Szostek and Schwartz (2015) failed to detect viruliferous onion thrips in cull piles composed of only decaying onion bulbs.

The purpose of this study was to gain insight into which habitats may be most influential in fostering IYSV epidemics in New York onion fields. To examine this question, we considered the abundance of viruliferous onion thrips captured in a habitat early to midseason as a proxy for identifying the relative contribution of that habitat to IYSV epidemics later in the season. Habitats sampled included those known to contain IYSV and its vector (i.e., transplanted onion fields, weedy areas near onion fields, and onion cull piles) as well as directseeded onion fields, which served as an early-season control because IYSV is not seed transmitted. We hypothesized that onion fields established with transplants imported from the southwestern United States would generate the greatest numbers of viruliferous thrips early to midseason compared with the other habitats. Such a scenario would create an opportunity for secondary spread of IYSV into adjacent onion fields (especially direct-seeded) and weedy habitats because onion thrips adults are known to disperse from maturing transplanted onion fields in search of other suitable habitats later in the season (Smith et al. 2017).

\section{Materials and Methods}

The study was conducted on the "Elba muck" near Elba, NY in 2014 and 2015. The Elba muck is in northwestern New York and spans two counties, Orleans and Genesee. The Elba muck is nearly 2,200 ha and approximately $50 \%$ of the area is planted annually to onion and about $35 \%$ is transplanted with onion imported from the southwestern United States. Onion plants are direct seeded from early April through midMay or transplanted from early April through early June. Onion bulbs are harvested from July to September. Most onion fields in the Elba muck are not rotated from year to year because such land is at a premium for onion production. The Elba muck was chosen as the study area because it is one of the largest onion production areas in the eastern United States and IYSV is frequently encountered, sometimes at very high levels (Hsu et al. 2010; Smith et al. 2015).

Sampling sites. Populations of adult onion thrips were monitored at a total of 16 sites representing the four habitat types: 4 weedy areas, 4 culled onion piles, 4 onion fields established with imported transplants, and 4 fields that were direct-seeded (Fig. 1). Weedy areas were located at least $10 \mathrm{~m}$ from an onion field and at least $60 \%$ of the area was dominated by weeds (Fig. 2a). Weedy area sites were also preferentially selected based on the presence of weed species known to be suitable hosts for both onion thrips and IYSV, and in areas where IYSV had been identified previously in perennial and biennial weed hosts (Smith et al. 2011). Areas designated as onion cull piles were located within approximately $2 \mathrm{~km}$ of onion fields and were dominated by culled onion bulbs and volunteer onion plants annually (Fig. 2b). Some of these onion cull piles previously had volunteer onion plants that tested positive for IYSV (Hsu et al. 2011). Transplanted onion sites were in fields transplanted with onion that originated from a farm in the southwestern United States (Fig. 2c). These imported plants had stems approximately 1.5 to $2 \mathrm{~cm}$ in diameter and two to three leaves at the time of transplanting in May. Each year, a subsample of imported onion plants was taken prior to transplanting from each of these field sites and then tested for IYSV using double-antibody sandwich enzyme-linked immunosorbent assay (DAS-ELISA) with commercially available antibodies and following the manufacturer's protocol (Agdia, Inc., Elkhart, IN). Direct-seeded onion fields were included as an early-season "negative" control because IYSV is not seed transmitted and, consequently, does not serve as an initial source of IYSV inoculum for thrips. Direct-seeded onion fields were seeded into fields in late April. Both transplanted and directseeded onion fields were devoid of volunteer onion plants, which were either absent or removed before the experiment was initiated. Transplanted onion sites were preferentially selected to feature fields with maturation times comparable with those of direct-seeded onion sites, based on cultivar and planting date, such that all sites were monitored for a similar period.

Sampling methods. Yellow sticky cards (Sentry MultiGuard; Great Lakes IPM, Vestaburg, MI) were used to monitor onion thrips flight activity in the various habitats. At each site, four yellow sticky cards $(7.6$ by $12.7 \mathrm{~cm})$ were placed $25 \mathrm{~m}$ apart along a transect spanning $100 \mathrm{~m}$. The sticky cards were mounted on wooden stakes and suspended approximately 60 to $92 \mathrm{~cm}$ from the ground (Fig. 2d). Yellow sticky cards were replaced weekly and stored at $-20^{\circ} \mathrm{C}$ until onion thrips could be morphologically identified and recorded (Moritz et al. 2001). Sampling of adult onion thrips was initiated in all habitats when transplanted onion had approximately four to five leaves and concluded when onion bulbs were harvested. In 2014, sampling began on 10 June and concluded on 4 September whereas, in 2015, sampling began on 1 June and ended 3 September. Numbers of adult onion thrips were binned into three sampling periods that approximately represented initial colonization of onion fields by onion thrips (early-season: 10 to 30 June 2014 and 1 June to 1 July 2015), dispersal of the first generation of onion thrips formed within the onion crop (midseason: 2 to 28 July 2014 and 2 to 30 July 2015), and dispersal of subsequent generations of onion thrips (late-season: 1 August to 4 September 2014 and 1 August to 3 September 2015). For each sampling period, the mean total number of adults/card/site was determined. Voucher specimens are maintained at the Department of Entomology at the New York State Agricultural Experiment Station in Geneva.

Plant species composition in weedy areas. Weed species and their prevalence were assessed at each weedy area. At each site, 10 quadrats of $1 \mathrm{~m}^{2}$ each were randomly placed immediately adjacent to the area where the yellow sticky cards were located (10 by $100 \mathrm{~m})$. All weed species were identified and botanically classified (family and species), including those known to be hosts for IYSV and onion thrips. The dominance of each species within each quadrat was visually assessed on a scale from 0 to $100 \%$, based on the area covered by that species; thus, $1 \%$ indicated that a weed species covered only $1 \%$ of the area and $100 \%$ indicated that the weed species covered $100 \%$ of the area within the quadrat. Weedy areas were assessed 17 July 2016 and $23 \mathrm{Au}$ gust 2016. All weedy areas were permanent, and were dominated by the same weed species in each year of the study.

IYSV detection in onion transplants. A subsample of imported onion plants was obtained from New York onion growers' warehouses prior to transplanting at each field site. Onion plants were imported from the southwestern United States, where IYSV is known to occur (Gent et al. 2006; Miller et al. 2006). Imported onion plants were grown in a greenhouse for 3 months in an attempt to increase IYSV titer levels. All onion plants were planted into pots $(7.6 \mathrm{~cm}$ in diameter by $31 \mathrm{~cm}$ tall) containing Cornell potting mix. Plants were treated with spinetoram at $1.9 \mathrm{~g} / \mathrm{liter}(\mathrm{AI})$ (Radiant; Dow AgroSciences, Inc., Indianapolis, IN) and spirotetramat at $1.9 \mathrm{~g} /$ liter (AI) (Movento; Bayer CropScience, Research Triangle Park, NC) to 
ensure that plants were thrips free and then grown in thrips-proof cages in the greenhouse. After 3 months, plants were tested for IYSV using DAS-ELISA. All samples were composites of leaf tissue from four onion plants weighing $1 \mathrm{~g}$. Leaf tissue was cut from inner leaves of the onion plant to increase the likelihood of detecting IYSV (Kritzman et al. 2001). ELISA outputs were analyzed with a BioTek ELx 800 platereader (BioTek, Winooski, VT). Samples were duplicated and the mean optical density reading for each sample was used to determine the sample absorbance. Mean absorbance values two times the negative control were deemed positive for IYSV. A positive composite sample was conservatively estimated to represent a single infected plant because there was a low frequency of samples testing positive for IYSV. Samples were tested 12 August 2014 and 30 July 2015.

IYSV detection in adult onion thrips. Thrips were tested for IYSV using reverse-transcriptase polymerase chain reaction (RTPCR) assays, as done in previous studies (Smith et al. 2015). Onion thrips adults were randomly selected and extracted from yellow sticky cards using a fine-tipped paint brush and $1 \mathrm{ml}$ of solvent (De-SolvIt; Orange-Sol Household Products, Inc., Gilbert, AZ). Paintbrushes were washed with ethanol between extractions to limit any potential contamination between onion thrips. Once removed, individual thrips were placed in a $0.5-\mathrm{ml}$ centrifuge tube (USA Scientific, Ocala, FL) and kept in a freezer $\left(-80^{\circ} \mathrm{C}\right)$ until processing. A subsample of six adult onion thrips was collected from each site (across all cards from that site) during each of the three sampling periods. Thus, at each of the 16 sites, 18 onion thrips adults were tested for IYSV each year.

Total RNA was isolated from individual thrips using modified procedures from the Omega MicroElute RNA Kit (Omega Bio-Tek, Norcross, GA). Individual thrips were processed by adding a working solution of TRK lysis buffer and $\beta$-mercaptoethanol $(\beta-\mathrm{me})(200 \mathrm{ml}$ of TRK buffer and $4.0 \mathrm{ml}$ of $\beta$-me per sample) paired with RNasefree, acid-washed glass beads (425 to $600 \mathrm{~mm}$, catalog number G8772-10G; Sigma-Aldrich, St. Louis). Thrips were homogenized at $30 \mathrm{~Hz}$ for $2 \mathrm{~min}$ using a Qiagen TissueLyser (Qiagen, Valencia, CA).

The diagnostic primers used to detect IYSV were IYSV-N402F 5'ACTCACCAATGTCTTCAAC-3' and IYSV-N402R 5'-GGCTTC CTCTGGTAAGTGC-3', which were designed from the $N$ gene of several IYSV isolates collected in New York in 2007 to 2008. To confirm the identity of onion thrips and quality of total RNA extracts, primers ThMCOI-F 5'-CGGGAACGGGATGAACAG- ${ }^{\prime}$ ' and ThMCOIR 5'-GGTCCCCTCCCCCTCTA-3', designed in the mitochondrial cytochrome oxidase subunit I gene sequence (GenBank accession number DQ228494), were used in a multiplex RT-PCR. Extracted total RNA was tested using the Qiagen one-step RT-PCR kit in a final volume of $12.5 \mu \mathrm{l}$ containing total thrips RNA (1 $\mu \mathrm{l})$, IYSV primers $(1.25 \mu \mathrm{l}, 1 \mathrm{mM}$ each), onion thrips MCOI primers $(0.625 \mu 1$, $0.1 \mathrm{mM}$ each), dNTP $(0.5 \mu \mathrm{l}, 10 \mathrm{mM}$ stock $), \mathrm{RNasin}(0.1 \mu \mathrm{l}), 5 \times$ buffer $(2.5 \mu \mathrm{l})$, enzyme mix $(0.5 \mu \mathrm{l})$, and sterile RNAse-free water $(4.15 \mu \mathrm{l})$. The thermal cycling conditions were as follows: $50^{\circ} \mathrm{C}$ for $30 \mathrm{~min}(1 \mathrm{cy}-$ cle); $95^{\circ} \mathrm{C}$ for $15 \mathrm{~min}$; followed by 40 cycles of $94^{\circ} \mathrm{C}$ for $30 \mathrm{~s}, 50^{\circ} \mathrm{C}$ for $1 \mathrm{~min}$, and $72^{\circ} \mathrm{C}$ for $1 \mathrm{~min}$; and a final extension at $72^{\circ} \mathrm{C}$ for $10 \mathrm{~min}$ (Bio-Rad Thermal Cycler). RT-PCR products (402 bp for IYSV and 325 bp for onion thrips) were stained with GelRed (Biotium, Hayward, CA) following electrophoresis on $1.5 \%$ agarose gels, then imaged using UV illumination.

Ten thrips that tested positive for IYSV in RT-PCR were randomly selected in each year to characterize their $N$ gene amplicons by sequencing after processing with ExoSAP-IT. Sequences (a total of $20 \mathrm{~N}$ gene nucleotide sequences) were analyzed and compared using the DNASTAR Lasergene software (version 14.1; DNASTAR, Madison, WI). This work confirmed the viruliferous nature of selected onion thrips.

Estimated number of viruliferous adult onion thrips. Detection of the IYSV $N$ gene in an individual thrips suggested that it was viruliferous. Past research has indicated a positive association between thrips testing positive for the nonstructural protein (NSs) gene, which indicates virus replication within the vector, and the coat protein $(N)$ gene (Birithia et al. 2013). To assess the relative importance of each habitat contributing to IYSV epidemics, the number of viruliferous onion thrips was estimated at each habitat type and sampling period each year. To estimate the number of viruliferous adults $\left(V_{s \mid p}\right)$ for each site and sampling period, the total number of onion thrips adults per card $\left(\sum t\right)$ within a site during a particular sampling period $(s \mid p)$ was multiplied by the incidence of viruliferous adult thrips $(\% I)$ within each site and sampling period $(s \mid p)$.

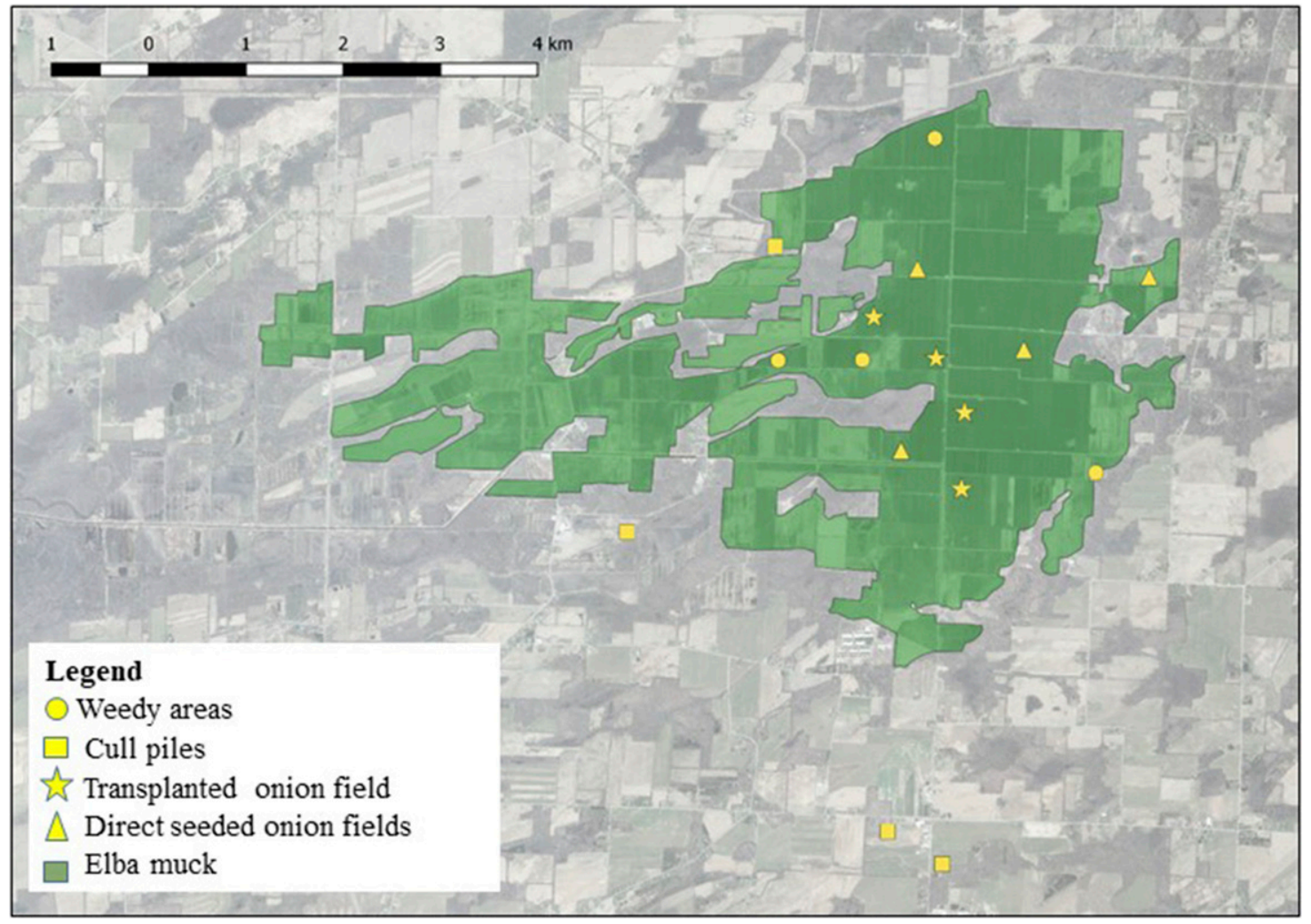

Fig. 1. Sites monitored for adult onion thrips within the Elba muck near Elba, NY in 2014 and 2015. 


$$
V_{s \mid p}=\sum t_{s \mid p} * \% I_{s \mid p}
$$

Viruliferous adults were estimated for each site over three sampling periods in 2014 and 2015 for a total of 96 data points (16 sites by three sampling periods by 2 years $=96$ ). Season total estimated viruliferous adult thrips per card was also determined for every site by summing the number of viruliferous thrips adults across all three sampling periods.

Statistical analysis. Data for each year were analyzed independently because weather and growing conditions were substantially different. Data were analyzed using a generalized linear mixed model (SAS PROC GLIMMIX, 2016; SAS Institute, Cary, NC). Habitat type was treated as a fixed effect and site replicate as a random effect.
All insect count data were analyzed using a negative binomial distribution. Total viruliferous thrips per card (thrips testing positive for IYSV by RT-PCR) were analyzed using a binomial distribution ( $n$ viruliferous thrips/total onion thrips captured). Differences in habitat types within each analysis were compared using least squared means $(P<0.05)$.

\section{Results}

Abundance of adult onion thrips across habitats. More adult onion thrips were captured in 2014 (total $=696$ thrips per site) than in 2015 (total $=468$ thrips per site). Total mean numbers of adults differed significantly among the habitat types in $2014(P=0.0008$, $\left.F_{3,44}=6.66\right)$ and $2015\left(P=0.0142, F_{2,43}=3.95\right)($ Table 1). Greatest
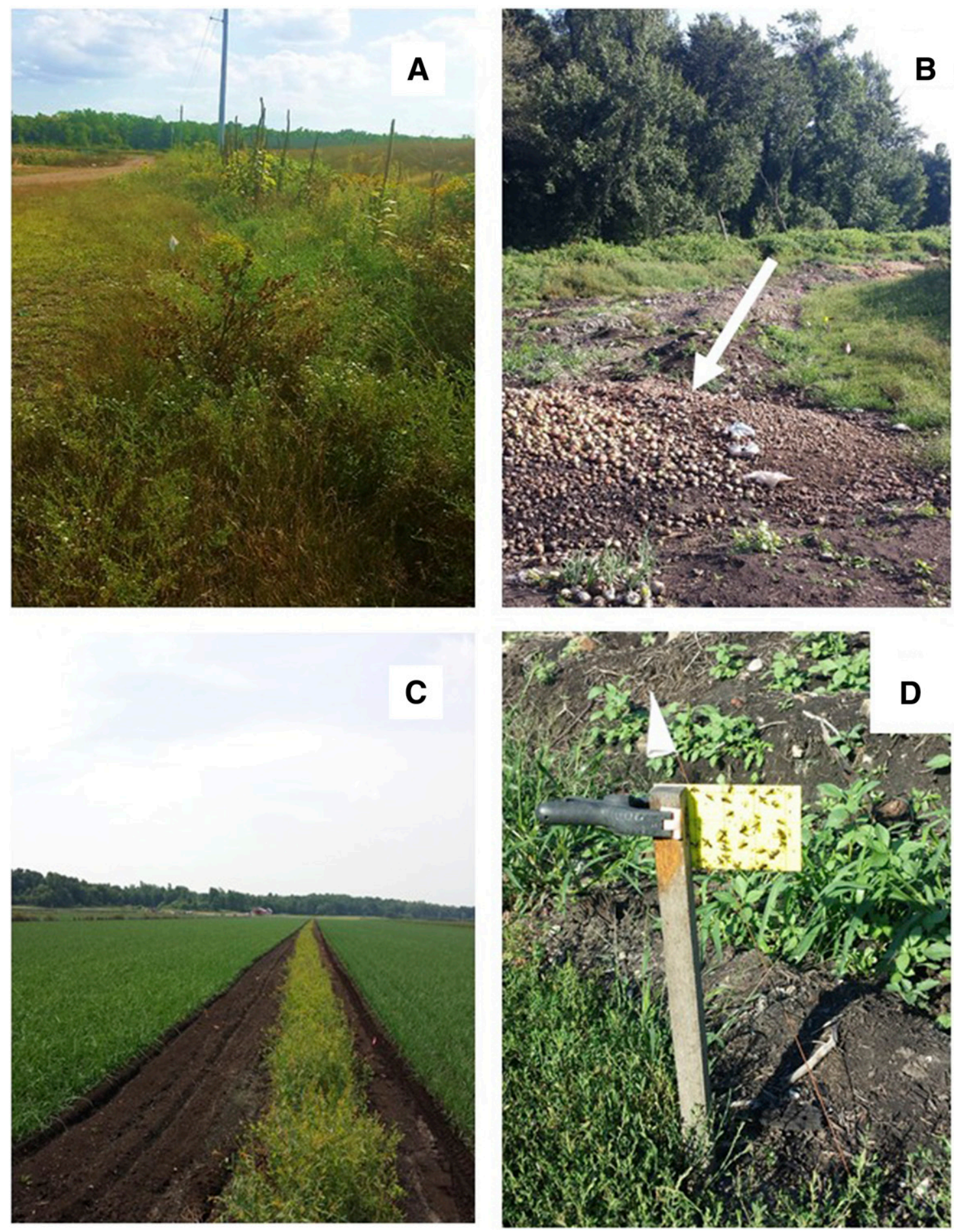

Fig. 2. Habitat types sampled for onion thrips adults. A, Weedy areas; B, onion cull piles; and C, transplanted and direct-seeded onion fields were monitored in western New York from June to early September 2014 and 2015. D, Adult onion thrips were monitored weekly using yellow sticky cards. 
numbers of thrips were recorded in transplanted onion fields in both years (Table 1). However, numbers of thrips adults in transplanted fields were only significantly greater than those in culled onion sites. Numbers of adults in weedy areas were second highest followed by those in direct-seeded onion fields. Sites with culled onion bulbs had the fewest number of adult onion thrips (Table 1).

Consistently, across all habitats and years, fewer adults were captured early in the season compared with mid to late season (Fig. 3). In 2014 and 2015 early in the season, the total mean number of adults captured among habitats did not differ $(P>0.05)$ (Fig. 3). In 2014 and 2015 in the middle of the season, the total mean numbers of adults captured in transplanted onion fields were greater than those in the other habitats, although the difference was only significant in $2014\left(P=0.0017, F_{3,12}=4.15\right)$ (Fig. 3). Abundance of adults in the middle of the season did not differ between other habitat types. In 2014 and 2015 late in the season, total mean numbers of adults in transplanted onion, weedy areas, and direct-seeded onion were greater than those in culled onion bulbs but this difference was significant only in $2014\left(P=0.0032, F_{3,12}=8.12\right)$ (Fig. 3). Abundance of thrips in culled onion sites remained low for the entirety of the growing season, and never surpassed 30 thrips per card per sampling period.

Plant species composition in weedy areas. Between 11 and 36 plant species were recorded at each weedy area site (data not shown). The most common species were pigweed (Amaranthus spp.), followed by goldenrod (Solidago spp.) and wild raspberry (Rubus spp.). Amaranthus spp. were the most dominant weed species, and covered approximately $21 \pm 11 \%$ (mean \pm standard error) of the area sampled over the two dates. Of those four species capable of hosting onion thrips and IYSV in New York (Smith et al. 2011), only dandelion (T. officinale), common burdock (A. minus), and curly dock (R. crispus) were identified. The most common IYSV weed host encountered was dandelion, which occurred at $75 \%$ of the sites. Overall, known plant host species for both IYSV and onion thrips were not numerous, and covered only $6 \%$ of the total area sampled.

IYSV detection in imported onion plants. Most of the imported onion plants tested negative for IYSV in 2014 and 2015 (Table 2). In 2014, no onion ( 0 of 829 ) tested positive for IYSV, whereas $0.9 \%$ (7 of 798) tested positive in 2015, when three of six cultivars tested positive for IYSV: 1.5\% (3 of 194) for Brandt, 1.3\% (3 of 233) for Red Defender, and $0.6 \%$ (1 of 155) for Festival.

Onion thrips testing positive for IYSV. All 20 IYSV $N$ gene sequences from viruliferous thrips that were determined in this study

Table 1. Total seasonal number of onion thrips adults, percent viruliferous thrips, and number of viruliferous onion thrips in culled onion bulbs, transplanted onion fields, weedy areas, and direct-seeded onion fields near Elba NY in 2014 and $2015^{z}$

\begin{tabular}{|c|c|c|c|}
\hline Year, habitat type & $\begin{array}{c}\text { Number of } \\
\text { onion thrips } \\
\text { adults per card }\end{array}$ & $\begin{array}{c}\text { Seasonal } \\
\text { percent } \\
\text { viruliferous } \\
\text { thrips }\end{array}$ & $\begin{array}{c}\text { Number of } \\
\text { estimated } \\
\text { viruliferous } \\
\text { onion } \\
\text { thrips adults } \\
\text { per card }\end{array}$ \\
\hline \multicolumn{4}{|l|}{2014} \\
\hline Culled onion bulbs & $47 \pm 5 b$ & $4.5 \pm 1.6 \mathrm{a}$ & $2 \pm 1 \mathrm{a}$ \\
\hline $\begin{array}{l}\text { Transplanted } \\
\text { onion fields }\end{array}$ & $450 \pm 55 \mathrm{a}$ & $6.4 \pm 2.0 \mathrm{a}$ & $29 \pm 17 \mathrm{a}$ \\
\hline Weedy areas & $203 \pm 29 a$ & $4.8 \pm 1.9 \mathrm{a}$ & $10 \pm 5 \mathrm{a}$ \\
\hline $\begin{array}{r}\text { Direct-seeded } \\
\text { onion fields }\end{array}$ & $172 \pm 20 \mathrm{a}$ & $9.7 \pm 1.8 \mathrm{a}$ & $18 \pm 9 a$ \\
\hline \multicolumn{4}{|l|}{2015} \\
\hline Culled onion bulbs & $44 \pm 6 b$ & $11.4 \pm 1.1 \mathrm{~b}$ & $5 \pm 1 \mathrm{~b}$ \\
\hline $\begin{array}{l}\text { Transplanted } \\
\text { onion fields }\end{array}$ & $258 \pm 45 a$ & $30.6 \pm 2.6 \mathrm{a}$ & $79 \pm 14 \mathrm{a}$ \\
\hline Weedy areas & $229 \pm 72 a$ & $11.1 \pm 1.5 \mathrm{~b}$ & $25 \pm 19 a$ \\
\hline $\begin{array}{r}\text { Direct-seeded } \\
\text { onion fields }\end{array}$ & $219 \pm 66 \mathrm{a}$ & $20.8 \pm 1.6 \mathrm{ab}$ & $46 \pm 40 \mathrm{a}$ \\
\hline
\end{tabular}

\footnotetext{
${ }^{\mathrm{z}}$ Data are total mean \pm standard error. For each year, means within a column
} with the same letters are not significantly different $(P>0.05$; LSmeans). shared $99 \%$ nucleotide identity with IYSV sequences available in GenBank, including previous entries from New York (GenBank JQ973065.1), Washington State (GenBank JQ973066.1), Idaho (GenBank KF263487.1), Georgia (GenBank DQ838593.1), and Colorado (GenBank KF263484.1).

Overall, 576 individual thrips were tested for IYSV by RT-PCR (18 thrips per site by four habitat types by four replications per habitat type by 2 years $=576$ thrips). Incidence of adult onion thrips testing positive for IYSV was much lower in 2014 than in 2015. The overall mean incidence of viruliferous onion thrips across all habitats was 6 and 18\% in 2014 and 2015, respectively. In 2014, there were no significant differences in overall incidence of thrips testing positive for IYSV among the habitats. In 2015, overall incidence of viruliferous thrips captured in transplanted onion fields (31\% infected) was significantly greater than incidence of those from weedy areas and cull piles $\left(P=0.0107, F_{3,39}=4.26\right)$ but not direct-seeded onion sites ( $21 \%$ infected) (Table 1$)$. The seasonal mean incidences of IYSV in thrips from transplanted onion and direct-seeded onion were 1.5 to 3 times greater than those captured in cull piles or weedy areas.

The percentage of viruliferous adults captured in this study tended to be lower early in the season than mid to late season in both years but the trend was more obvious in 2015 (Fig. 4). In 2014, the percentage of viruliferous thrips captured among habitats did not differ during any of the sampling periods $(P>0.05)$ (Fig. 4). Early in the 2015 season, the percentage of viruliferous thrips captured among habitats did not differ $(P>0.05)$. In the middle of the 2015 season, the percentage of viruliferous thrips in transplanted onion fields was numerically higher than those in the other habitats but the difference only approached significance $(P=0.08)$ (Fig. 4). Percentages of viruliferous thrips in the other habitats did not differ. Late in the season in 2015 , the percentages of viruliferous thrips in transplanted onion fields and direct-seeded onion fields were significantly greater than those in the other habitats $\left(P=0.0370, F_{3,11}=4.03\right)$.

Estimated number of viruliferous adult onion thrips. Although there were more thrips captured in 2014 than 2015, estimated numbers of viruliferous adults were higher in 2015 (39 per card) than in 2014 (15 per card). Despite 10- to 20 -fold differences in total estimated numbers of viruliferous thrips among some habitat types in 2014, none were significant $(P>0.05)$ (Table 1). In 2014, there were, overall, numerically more viruliferous thrips estimated from transplanted onion fields than in the other habitats. In 2015, estimated numbers of viruliferous thrips in transplanted onion fields were significantly greater than those in culled onion bulbs and similar to those in weedy areas and direct-seeded onion fields $\left(P=0.0094, F_{3,42}=\right.$ 4.34) (Table 1). Transplanted onion fields had the greatest total number of estimated viruliferous thrips and accounted for 49 to $51 \%$ of total estimated numbers of viruliferous thrips in 2014 and 2015 compared with the other habitat types (Table 1). In both years, the lowest seasonal total estimates of viruliferous thrips were from cull piles, which accounted for only 4 to $5 \%$ of the total.

The lowest estimated numbers of viruliferous individuals occurred early in the season each year and there were no differences among habitat types $(P>0.05)$ (Fig. 5). In 2014 and 2015 in the middle of the season, the estimated numbers of viruliferous adults in transplanted onion fields were greater than those in the other habitats but this difference was only significant in $2015\left(P=0.0296, F_{3,11}=\right.$ 4.36) (Fig. 5). In 2014 and 2015 late in the season, the estimated total numbers of viruliferous adults in transplanted onion fields, weedy areas, and direct-seeded onion fields were greater than those in culled onion bulbs but none of the differences were significant $(P>0.05)$ (Fig. 5). Temporally, there were numerical differences between estimated numbers of viruliferous thrips within the season (Fig. 5). Early in the season, cull pile sites had the greatest number of viruliferous thrips per card, and accounted for between 65 and $86 \%$ of total viruliferous thrips. Transplanted onion sites had the greatest number of estimated viruliferous thrips during the midseason period, and accounted for 83 and 76\% of the total in 2014 and 2015, respectively. Late in the season in both years, direct-seeded onion fields had the highest densities of estimated viruliferous thrips, and 
accounted for the highest percentages of estimated viruliferous thrips (48\% in 2014 and $62 \%$ in 2015).

\section{Discussion}

Onion thrips adults and IYSV were detected in all habitat types over the duration of the study. However, fields transplanted with imported onion plants had the greatest densities of onion thrips and highest seasonal incidences of viruliferous adults compared with other potential IYSV source habitats (weedy areas and culled onion sites). Moreover, transplanted onion sites accounted for 49 to $51 \%$ of the total estimated numbers of viruliferous thrips. From early to midseason, transplanted onion fields had 9 to 11 times more viruliferous thrips compared with the other habitats. Because onion thrips adults colonize and reproduce in transplanted onion fields in late May and June, viruliferous adult thrips captured from these fields during midseason in July were likely the progeny of the original colonizers. As we hypothesized, the overwhelming abundance of viruliferous adult thrips in transplanted onion fields during midseason compared with those in culled onion sites and weedy areas strongly suggests that transplanted onion plants are the most important habitat for generating IYSV epidemics in all onion fields (transplanted and direct-seeded) later in the season.

The incidence of thrips testing positive for IYSV was three times greater in 2015 than 2014. One potential reason for this difference in viruliferous onion thrips populations may be the number of imported transplants that were infected with IYSV. Multiple studies have suggested that onion transplants may reintroduce IYSV annually into the onion production system (Gent et al. 2006; Hsu et al. 2010; Schwartz et al. 2014). Low levels of IYSV found in transplants prior to planting may supply inoculum to initiate epidemics later in the season (Gent et al. 2006; Hsu et al. 2011). In 2014, subsamples of transplants coming into New York from the southwestern United States all tested negative for IYSV (0 of 829 transplants). In contrast, in 2015, 7 of 798 transplants $(0.9 \%)$ tested positive for IYSV. Although this is a low initial percentage of infected plants, it would have provided enough initial inoculum to foster the higher IYSV incidences in onion thrips observed in 2015. For example, New York onion growers often transplant approximately 642,500 onion bulbs/ha. If $0.9 \%$ of the plants arrived already infected with IYSV, there would be a starting inoculum level of 578 IYSV-infected plants/ha. In the Elba muck,

Table 2. Number of imported onion plants testing positive for Iris yellow spot virus (IYSV) using double-antibody sandwich enzyme-linked immunosorbent assay after being maintained in thrips-proof cages in a greenhouse for 3 months in 2014 and $2015^{z}$

\begin{tabular}{lccccc}
\hline & \multicolumn{3}{c}{ Number of samples tested for IYSV } \\
\cline { 2 - 3 } \cline { 2 - 3 } Onion cultivar & Total & Positive & & Total & Positive \\
\hline Brandt & 173 & 0 & & 194 & 3 \\
Red Defender & 204 & 0 & & 233 & 3 \\
Delgado & 181 & 0 & & 216 & 0 \\
Festival & 167 & 0 & & 155 & 1 \\
Moondance & 104 & 0 & & $\ldots$ & $\ldots$ \\
Total tested & 829 & 0 & 798 & 7 \\
\hline
\end{tabular}

${ }^{\mathrm{z}}$ Plants were obtained before transplanting in the field.

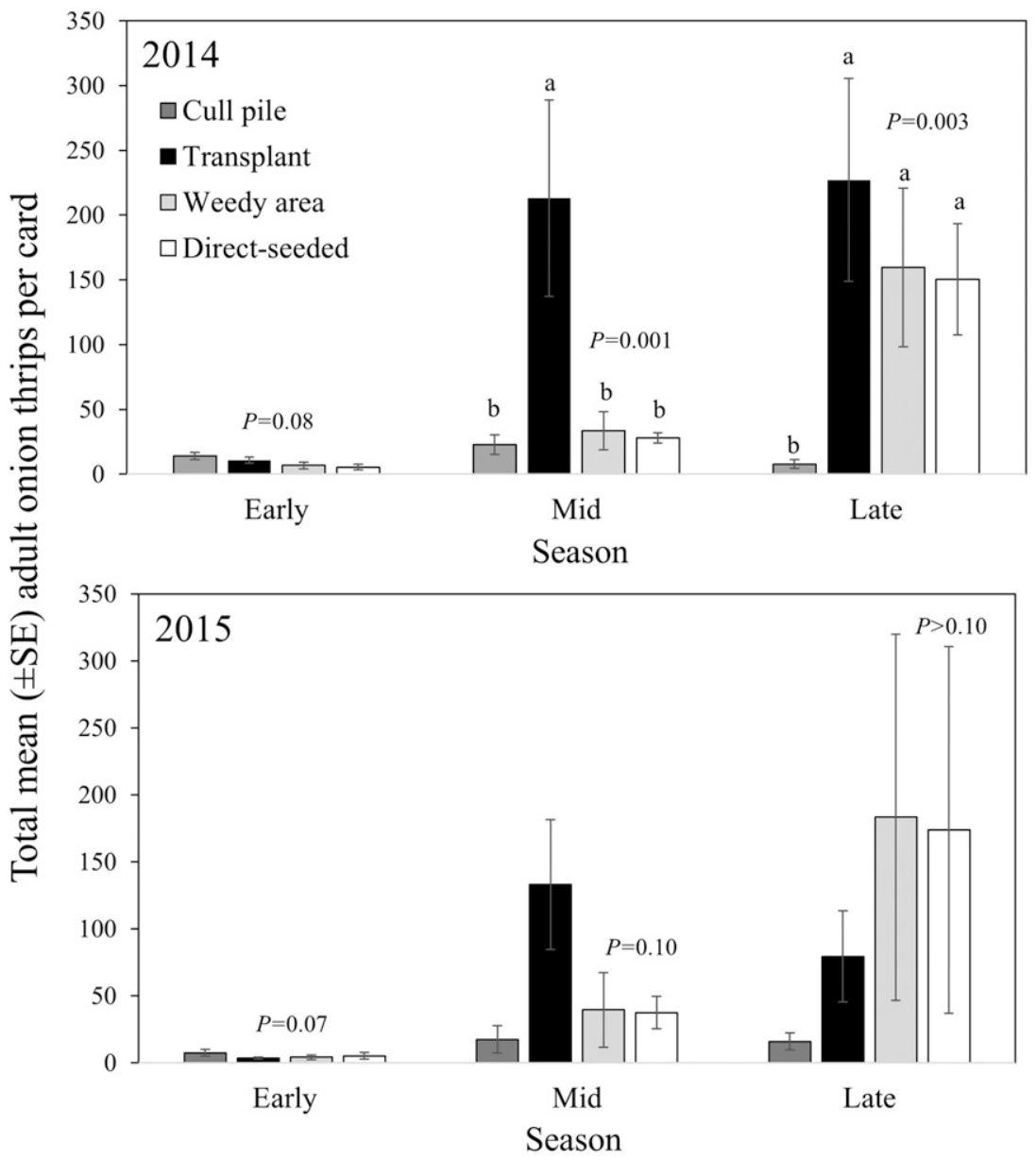

Fig. 3. Mean ( \pm standard error [SE]) number of onion thrips adults per card per sampling period within four habitat types (onion cull piles, transplanted onion fields, weedy areas, and direct-seeded onion fields) near Elba, NY in 2014 and 2015. Thrips were morphologically identified to species. In both years, sampling was initiated when onion plants had one to four leaves, and concluded with onion harvest. 
land is partitioned into a series of 4-ha fields, which would create a series of transplanted onion fields each starting with an estimated 2,300 IYSV-infected plants. Because a large portion of the Elba muck is planted using imported onion transplants, this can further increase IYSV inoculum in the onion production system.

Regardless of initial infection of imported onion plants, transplanted onion fields are likely an important habitat for IYSV inoculum, because transplanted onion serves as a highly attractive homogenous IYSV host early in the season. Notably, zero onion plants tested positive for IYSV in 2014; however, large populations of viruliferous thrips were estimated in transplanted onion fields. In early to midseason, over $60 \%$ of thrips were captured in fields planted with imported transplants and only $15 \%$ in weedy areas, $10 \%$ in culled onion bulbs, and $14 \%$ in direct-seeded onion fields. Hsu et al. (2010) reported that onion plants in transplanted fields had approximately $20 \%$ more onion thrips than those in direct-seeded fields early in the growing season. Preferential colonization of transplanted onion fields by onion thrips early in the season may have important epidemiological consequences when combined with the presence of IYSV-infected transplants, because it likely contributes to a large population of thrips acquiring IYSV early in the growing season.

In both years of this study, a temporal increase in the number of viruliferous adult thrips was observed in direct-seeded onion fields later in the season, which was likely due to immigration of adult thrips from adjacent, senescing transplanted onion fields. Our results showed that numbers of viruliferous adults peaked in transplanted sites in midseason of each year, whereas the number of viruliferous thrips in direct-seeded sites peaked a month later (in August). Approximately 76 to $83 \%$ of the estimated viruliferous thrips were recorded in transplanted onion fields midseason. However, in August, the majority
$(55 \%)$ of viruliferous thrips occurred in direct-seeded onion fields. Higher onion thrips populations at the end of the growing season in direct-seeded fields compared with transplanted onion fields have been previously reported in the Elba muck by Hsu et al. (2010) and Smith et al. (2017). Smith et al. (2011) also reported spikes in populations of onion thrips in weedy areas late in the season when onion fields were harvested. Because direct-seeded onion fields are not an initial source of IYSV (Kritzman et al. 2001), the high number of viruliferous adults in direct-seeded onion fields later in the season suggests secondary spread of the virus from initial sources of IYSV inoculum from transplanted fields. As the season progresses, viruliferous adults likely disperse to new sites that contain attractive hosts. In this production system, transplanted onion fields are planted adjacent to and simultaneously with direct-seeded fields, which facilitates movement of thrips between fields of differing developmental stages. Therefore, transplanted onion fields foster secondary spread of IYSV into nearby direct-seeded onion fields.

Viruliferous onion thrips were recorded in weedy areas and may also contribute to IYSV epidemics. However, we found that seasonal incidence of IYSV in weedy areas was lower than incidence in transplanted onion fields. Two potential reasons for this finding include fewer IYSV plant hosts in weedy areas and reduced fecundity of onion thrips on non-onion plant hosts. In New York, only four biennial or perennial plant species (i.e., dandelion, common burdock, curly dock, and chicory) have been demonstrated to be hosts of both onion thrips larvae and IYSV (Smith et al. 2011). In our study, we found that three of those species were present and composed only $6 \%$ of the weedy areas sampled. Thus, onion thrips were much less likely to encounter a suitable IYSV plant host in a weedy area versus an onion field. Additionally, studies have shown that thrips numbers are

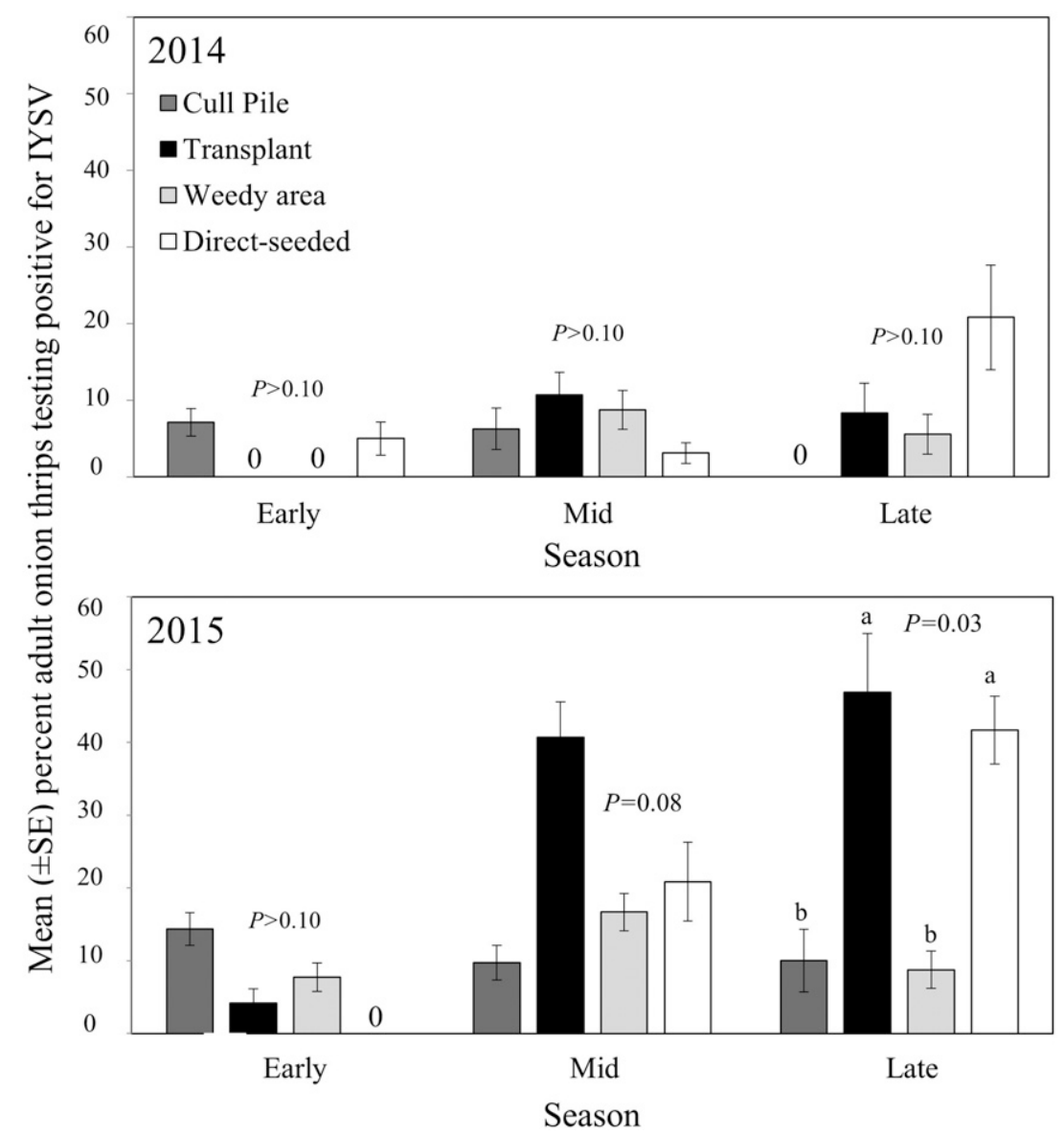

Fig. 4. Mean ( \pm standard error [SE]) percent onion thrips adults testing positive for Iris yellow spot virus (IYSV) per sampling period within four habitat types (onion cull piles, transplanted onion fields, weedy areas, and direct-seeded onion fields) that may foster IYSV epidemics near Elba, NY in 2014 and 2015. In both years, sampling was initiated when onion plants had one to four leaves, and concluded with onion harvest. 
lower on weedy IYSV hosts compared with numbers on onion plants (Nischwitz et al. 2012; Smith et al. 2011). Notably, we found that Amaranthus spp. were common in the weedy areas sampled. Although Amaranthus spp. are hosts of IYSV (Sampangi et al. 2007), they are a poor-quality host for onion thrips (Schwartz et al. 2014; Smith et al. 2011). Smith et al. (2011) found that, of the 25 weed species sampled, none exceeded more than six thrips per plant over the course of the growing season. In onion, onion thrips densities can easily exceed 100 per leaf (Fournier et al. 1995).

At the end of each growing season, onion thrips likely migrate to weedy areas adjacent to onion fields. Like Smith et al. (2011), we observed large abundances of adult onion thrips in weedy areas on the last date of sampling. In New York, onion thrips can produce six to eight generations, with two to three of those generations occurring exclusively on non-onion plant hosts (Hoffmann et al. 1996). Therefore, as adult onion thrips move into weedy areas from onion fields, viruliferous thrips populations may decrease because thrips are less likely to encounter an IYSV plant host on which to feed and oviposit. Even if an adult successfully colonizes a plant that is a host for both the virus and vector, fewer progeny will likely be supported on that plant, which might reduce the overwintering population of viruliferous thrips in the subsequent season. However, it should be noted that we did detect viruliferous adults in weedy areas as early as June, indicating that weeds may still provide a green bridge by which IYSV can persist (Hsu et al. 2010, Nischwitz et al. 2012, Schwartz et al. 2014, Smith et al. 2011).

The fewest numbers of adult onion thrips and those estimated to be viruliferous were captured near culled onion bulbs in both years of the study. Cull piles are unlikely to greatly contribute to IYSV inoculum via viruliferous onion thrips populations. These results are like those found by Szostek and Schwartz (2015), who reported few to zero thrips in cull piles. Like Szostek and Schwartz (2015), the cull pile sites in our study were likely poor habitats for onion thrips populations because they were dominated by decaying onion bulbs. Although cull piles do not appear to contribute greatly to the overall amount of viruliferous adults in the landscape, thrips captured near cull piles had relatively high levels of IYSV early in the growing season. High percentages of viruliferous thrips were captured near cull pile sites early in the season in 2014 and 2015 (65 and 86\%, respectively), and could potentially initiate virus epidemics if they emigrated to nearby onion fields. However, a relatively low percentage of adult onion thrips engage in long-distance dispersal, and even fewer do so early in the onion growing season (Smith et al. 2015). Nevertheless, cull piles should be spatially separated from onion fields to limit risk of viruliferous thrips migrating into onion fields.

Our results add to the growing body of literature addressing factors influencing the risk and development of iris yellow spot disease in onion. Our study is the first to estimate the relative significance of habitats containing IYSV sources in the landscape by surveying populations of viruliferous adult onion thrips. Although we detected viruliferous adult thrips in all habitat types known to harbor IYSV, fields planted with imported onion transplants had the highest incidence of viruliferous onion thrips. Additionally, we consistently observed that transplanted onion fields had the greatest abundance of dispersing viruliferous thrips in the middle of the growing season (July). Therefore, onion thrips control in transplanted onion fields may be a priority for onion growers, especially early in the season, to reduce risk of IYSV spread to other onion fields later in the season. To potentially reduce the risk of viruliferous thrips dispersing from maturing transplanted

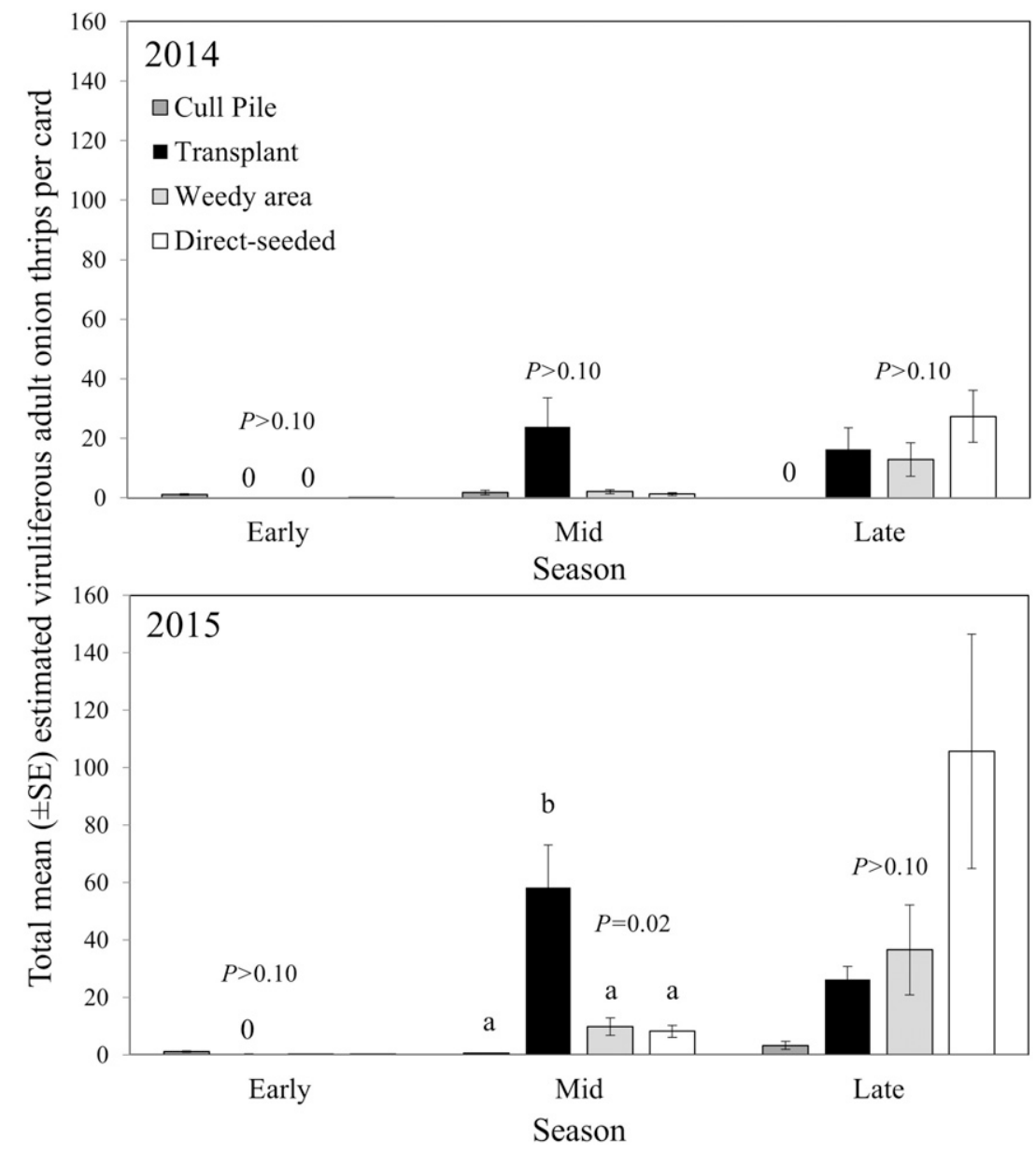

Fig. 5. Mean ( \pm standard error [SE]) estimated number of viruliferous adult onion thrips early, middle, and late in the growing season (June, July, and August, respectively) within four habitat types (onion cull piles, transplanted onion fields, weedy areas, and direct-seeded onion fields) that may contribute to Iris yellow spot virus epidemics near Elba, NY in 2014 and 2015. In both years, sampling was initiated when onion plants had one to four leaves, and concluded with onion harvest. 
fields into direct-seeded onion fields, growers may consider spatially isolating onion fields planted with imported onion transplants from direct-seeded onion fields.

\section{Acknowledgments}

We thank Torrey Farms, Mortellaro Farms, and Triple G Farms for allowing us to conduct research on their property; M. Cappiello and D. Ritter for collecting data; R. Cox for conducting all DAS-ELISA testing; D. Olmstead for the assistance with the figures; and P. Marsella-Herrick and E. Cieniewicz for their technical assistance with RT-PCR.

\section{Literature Cited}

Bag, S., Schwartz, H. F., Cramer, C. S., Havey, M. J., and Pappu, H. R. 2015. Iris yellow spot virus (Tospovirus: Bunyaviridae): From obscurity to research priority. Mol. Plant Pathol. 16:224-237.

Birithia, R., Subramanian, S., Pappu, H. R., Muthomi, J., and Narla, R. D. 2013. Analysis of Iris yellow spot virus replication in vector and non-vector thrips species. Plant Pathol. 62:1407-1414.

Cortês, I., Livieratos, I. C., Derks, A., Peters, D., and Kormelink, R. 1998. Molecular and serological characterization of Iris yellow spot virus, a new and distinct tospovirus species. Phytopathology 88:1276-1282.

Cramer, C. S., Singh, N., Kamal, N., and Pappu, H. R. 2014. Screening onion plant introduction accessions for tolerance to onion thrips and iris yellow spot. HortScience 49:1253-1261.

De Avila, A. C., Gama, M. I. C., Kitajima, E. W., and Pereira, W. 1981. Um virus do grupo vira-cabeca do tomateiro isolado de cebola (Allium cepa L.). Fitopatol. Bras. 6:525.

Diaz-Montano, J., Fail, J., Deutschlander, M., Nault, B. A., and Shelton, A. M. 2012. Characterization of resistance, evaluation of the attractiveness of plant odors, and effect of leaf color on different onion cultivars to onion thrips (Thysanoptera: Thripidae). J. Econ. Entomol. 105:632-641.

Doederlein, T. A., and Sites, R. W. 1993. Host plant preferences of Frankliniella occidentalis and Thrips tabaci (Thysanoptera: Thripidae) for onions and associated weeds on the Southern High Plains. J. Econ. Entomol. 86:17061713

Evans, C. K., Bag, S., Frank, E., Reeve, J., Ransom, C., Drost, D., and Pappu, H. R. 2009. Green foxtail (Setaria viridis), a naturally infected grass host of Iris yellow spot virus in Utah. Plant Dis. 93:670.

Fournier, F., Boivin, G., and Stewart, R. K. 1995. Effect of Thrips tabaci (Thysanoptera: Thripidae) on yellow onion yields and economic thresholds for its management. J. Econ. Entomol. 88:1401-1407.

Gent, D. H., du Toit, L. J., Fichtner, S. F., Mohan, S. K., Pappu, H. R., and Schwartz, H. F. 2006. Iris yellow spot virus: An emerging threat to onion bulb and seed production. Plant Dis. 90:1468-1480.

Hoffmann, M. P., Petzoldt, C. H., and Frodsham, A. C. 1996. Page 78 in: Integrated Pest Management for Onions. Cornell University, Ithaca, NY.

Hsu, C. L., Hoepting, C. A., Fuchs, M., Shelton, A. M., and Nault, B. A. 2010. Temporal dynamics of Iris yellow spot virus and its vector, Thrips tabaci (Thysanoptera: Thripidae), in seeded and transplanted onion fields. Environ. Entomol. 39:266-277.

Hsu, C. L., Hoepting, C. A., Fuchs, M., Smith, E. A., and Nault, B. A. 2011. Sources of Iris yellow spot virus in New York. Plant Dis. 95:735-743.
Kritzman, A., Lampel, M., Raccah, B., and Gera, A. 2001. Distribution and transmission of Iris yellow spot virus. Plant Dis. 85:838-842.

Miller, M. E., Saldana, R. R., Black, M. C., and Pappu, H. R. 2006. First report of Iris yellow spot virus on onion (Allium cepa) in Texas. Plant Dis. 90:1359.

Moritz, G., Morris, D. C., and Mound, L. A. 2001. ThripsID: Pest Thrips of the World. An Interactive Identification and Information System. CDROM published by ACIAR, Australia. CSIRO Publishing, Melbourne, Australia.

Nagata, T., Inoue-Nagata, A. K., Smid, H. M., Goldbach, R., and Peters, D. 1999. Tissue tropism related to vector competence of Frankliniella occidentalis for tomato spotted wilt tospovirus. J. Gen. Virol. 80:507-515.

Nischwitz, C., Srinivasan, R., Sundaraj, S., Mullis, S. W., McInnes, B., and Gitaitis, R. D. 2012. Geographical distribution and survival of Iris yellow spot virus in spiny sowthistle, Sonchus asper, in Georgia. Plant Dis. 96: $1165-1171$

Pozzer, L., Bezerra, I. C., Kormelink, R., Prins, M., Peters, D., Resende, R. de O. and de Ávila, A. C. 1999. Characterization of a tospovirus isolate of Iris yellow spot virus associated with a disease in onion fields in Brazil. Plant Dis. 83: 345-350.

Rueda, A., Badenes-Perez, F. R., and Shelton, A. M. 2007. Developing economic thresholds for onion thrips in Honduras. Crop Prot. 26:1099-1107.

Sampangi, R. K., Mohan, S. K., and Pappu, H. R. 2007. Identification of new alternative weed hosts for Iris yellow spot virus in the Pacific Northwest. Plant Dis. 91:1683.

Schwartz, H. F., Gent, D. H., Fichtner, S. M., Hammon, R., Cranshaw, W. S., and Mahaffey, L. 2009. Straw mulch and reduced-risk pesticide impacts on thrips and Iris yellow spot virus on Western-grown onions. Southwest. Entomol. 34:13-29.

Schwartz, H. F., Gent, D. H., Fichtner, S. M., Otto, K., Boateng, C. O., and Szostek, S. 2014. Thrips tabaci (Thysanoptera: Thripidae) and Iris yellow spot virus associated with onion transplants, onion volunteers, and weeds in Colorado. Southwest. Entomol. 39:691-704.

Smith, E. A., Ditommaso, A., Fuchs, M., Shelton, A. M., and Nault, B. A. 2011 Weed hosts for onion thrips (Thysanoptera: Thripidae) and their potential role in the epidemiology of Iris yellow spot virus in an onion ecosystem. Environ. Entomol. 40:194-203.

Smith, E. A., Fuchs, M., Shields, E. J., and Nault, B. A. 2015. Long-distance dispersal potential for onion thrips (Thysanoptera: Thripidae) and Iris yellow spot virus (Bunyaviridae: Tospovirus) in an onion ecosystem. Environ. Entomol. 44:921-930.

Smith, E. A., Shields, E. J., and Nault, B. A. 2017. Onion thrips colonization of onion fields bordering crop and non-crop habitats in muck cropping systems. J. Appl. Entomol. 141:574-582.

Srinivasan, R., Sundaraj, S., Pappu, H. R., Diffie, S., Riley, D. G., and Gitaitis, R. D. 2012. Transmission of Iris yellow spot virus by Frankliniella fusca and Thrips tabaci (Thysanoptera: Thripidae). J. Econ. Entomol 105:40-47.

Szostek, S., and Schwartz, H. F. 2015. Overwintering sites of Iris yellow spot virus and Thrips tabaci (Thysanoptera: Thripidae) in Colorado. Southwest. Entomol. 40:273-290.

Ullman, D. E., Meideros, R., Campbell, L. R., Whitfield, A. E., Sherwood, J. L., and German, T. L. 2002. Thrips as vectors of tospoviruses. Adv. Bot. Res. 36:113-140.

Whitfield, A. E., Ullman, D. E., and German, T. L. 2005. Tospovirus-thrips interactions. Annu. Rev. Phytopathol. 43:459-489. 